\title{
Kosovo's Quest for Council of Europe Membership
}

\author{
Kushtrim Istrefi ${ }^{1}$ \\ University of Amsterdam, The Netherlands \\ <kushtrim.istrefi@gmail.com>
}

\begin{abstract}
In 2014, Kosovo became a member of two Council of Europe (CoE) partial agreements: on the Development Bank and on the European Commission for Democracy through Law (the Venice Commission). More recently, the Government of Kosovo expressed an interest in joining the CoE. This article examines, in the context of Kosovo's contested statehood, the conditions and procedure for Kosovo's possible admission to the CoE and describes, in the form of an early warning, the key legal and policy issues that could arise in this process. Insofar as membership criteria are concerned, the article examines Kosovo's ability to exercise jurisdiction over its territory. In this regard, the case of Azemi v. Serbia before the European Court of Human Rights (ECtHR or the Strasbourg Court) and the EU-facilitated agreements between Belgrade and Pristina are considered. In addition, the article argues that that the direct applicability of the European Convention for the Protection of Human Rights and Fundamental Freedoms (ECHR) and the ECtHR's case law in Kosovo are evidence of Kosovo's commitment to fulfilling one of the essential membership criteria. Regarding Kosovo's prospects for admission, the article submits that the recognition of Kosovo by more than two-thirds of the Council's member states is an indicator that, in principle, Kosovo could ensure the votes necessary for admission. However, it also highlights the specific challenges Kosovo may encounter in its membership path due to complex admission procedures within the CoE Committee of Ministers and the composition of the members of the CoE Parliamentary Assembly (PACE).
\end{abstract}

1 Dr. Kushtrim Istrefi teaches EU Law and International Security at the University of Amsterdam and International Law Clinic at the vu University Amsterdam. He is also a visiting lecturer in Human Rights Law at the Riga Graduate School of Law.

(C) ISTREFI, 2018 | DOI 10.1163/15730352-04303002

This is an open access article distributed under the terms of the prevailing CC-BY-NC license at the time of publication. 


\section{Keywords}

Council of Europe - Kosovo - membership - jurisdiction - Serbia

\section{Introduction}

The international community's divide over recognizing Kosovo has made its admission to international organizations particularly challenging. It appears that Kosovo has been able to attain membership only in those organizations where unanimity was unnecessary and no veto rights could be exercised. ${ }^{2}$ Kosovo has generally applied for membership in international organizations after having secured the necessary votes from both recognizing and some nonrecognizing states. ${ }^{3}$ Having already joined the International Monetary Fund, ${ }^{4}$ the World Bank, ${ }^{5}$ and certain other international bodies, Kosovo has expressed its wish to accede to the Council of Europe (CoE). The fact that Kosovo has been recognized by more than two-thirds of CoE member states is an indicator that, in principle, Kosovo could ensure the votes necessary for its admission. ${ }^{6}$

2 For example, Kosovo became a member of the World Bank and the International Monetary Fund on 29 June 2009. Membership in these organizations is not decided by unanimity. For more, see Besfort Rrecaj, "A Contemporary Interpretation of the Principles of Sovereignty, Territorial Integrity and Self-Determination, and the Kosovo Conundrum", in James Summers (ed.), Kosovo: A Precedent? (Martinus Nijhoff Publishers, Boston, 2011), 134.

3 In 2017, for example, the Government of Kosovo withdrew its application for membership in Interpol due to a lack of reliable information concerning the number of countries that would support Kosovo's accession to the organization. See "Kosovo Abandons Bid to Join Interpol This Year", BalkanInsight (21 September 2017), available at <http://www.balkaninsight .com/en/article/kosovo-abandons-bid-to-join-interpol-this-year-09-21-2017>; “Sefaj: Kosovo to renew Interpol Membership Bid in November", RTKLive (28 February 2018), available at $<$ https://www.rtklive.com/en/news-single.php?ID=10900 $>$. It should be noted that Kosovo failed to secure the votes necessary to become a member of the United Nations Educational, Scientific and Cultural Organization. See "Kosovo fails in unesco membership bid", The Guardian (9 November 2015).

4 Kosovo became a member of the International Monetary Fund on 29June 2009. See "Kosovo Becomes the International Monetary Fund's 186th Member", IMF.org (29 June 2009), available at <https://www.imf.org/en/News/Articles/2015/og/14/01/49/prog240 >.

5 Kosovo became a member of the World Bank on 29 June 2009. See World Bank, Member Countries, available at <http://www.worldbank.org/en/about/leadership/members $>$.

6 Art.20 of the CoE's Statute provides that accession to the Council requires a two-thirds majority of all of the representatives of the Committee of Ministers. The following 34 out of 47 
In 2012, Kosovo established a diplomatic office in Strasbourg. Two years later, it became a member of the CoE Development Bank and the Venice Commission, ${ }^{7}$ creating new momentum on the country's path to CoE membership. At the same time, this path is expected to be a bumpy one as long as Serbia, a member of the CoE, considers Kosovo part of its territory.

Against this background, this article discusses Kosovo's quest for CoE membership in the following order. First, it analyses the CoE membership criteria and their application in practice, including in the context of disputed territories. Second, it scrutinizes Kosovo's ability to fulfill these membership criteria. Third, it analyses the CoE's admission procedure and highlights some political aspects in this regard that should not be overlooked. Finally, the concluding remarks discuss the prospects for Kosovo's admission to the $\mathrm{CoE}$.

\section{CoE Membership Criteria and Their Application in Practice}

The CoE's membership criteria are specified in Articles 3 and 4 of its Statute. ${ }^{8}$ According to Article 3, the CoE may grant membership to a state that accepts "the principles of the rule of law and of the enjoyment by all persons within its jurisdiction of human rights and fundamental freedoms, and [that collaborates] sincerely and effectively in the realization of the aim of the Council as specified in Chapter I". It follows from Article 3 that compliance with the rule of law and human rights standards is essential. The broad language of Article 3 allows PACE, a CoE institution empowered to assess the membership criteria and to determine, on a case-by-case basis, which standards in the areas of human rights and rule of law a state has to fulfill to join the organization. Article 3 also allows PACE to establish new conditions. After the fall of the Berlin Wall, for example, PACE established the principle that all candidate states

member states of the Council of Europe have recognized Kosovo as an independent state: Albania, Andorra, Austria, Belgium, Bulgaria, Croatia, Czech Republic, Denmark, Estonia, Finland, France, Germany, Hungary, Iceland, Ireland, Italy, Latvia, Liechtenstein, Lithuania, Luxembourg, Malta, Monaco, Montenegro, Netherlands, Norway, Poland, Portugal, San Marino, Slovenia, Sweden, Switzerland, the former Yugoslav Republic of Macedonia, Turkey and United Kingdom.

7 The Development Bank and the Venice Commission were established through partial agreements of the CoE Committee of Ministers. For CoE partial agreements, see CoE, Partial Agreements, available at <http://conventions.coe.int/Treaty/Commun/ListeTousAP .asp?CL=ENG $>$.

8 Art.4 of the Statute, op.cit. note 5 . 
must accept and ratify the ECHR. ${ }^{9}$ Regarding collaboration in the realization of the Council's aims as outlined in Chapter I, this primarily establishes a general duty to cooperate. ${ }^{10}$

Pursuant to Article 4, membership in the $\mathrm{CoE}$ is limited to European states that are able and willing to comply with the membership criteria as specified in Article 3. This criterion may prove relevant in the context of contested states and territories, as it requires that a candidate state be not only willing but also able to ensure human rights and the rule of law for everyone within its jurisdiction.

Against this background, Article 3 provides substantive membership criteria, describing the standards a state has to fulfil to become a member. Article 4 provides a capacity membership criterion, describing the control a state has to exercise over its territory to ensure the implementation of human rights and the rule of law. These two aspects of the CoE's membership criteria will be examined by looking at the CoE's admission policy in the past. This will help determine what issues under Articles 3 and 4 could be triggered in Kosovo's quest for CoE membership.

\subsection{Human Rights and the Rule of Law}

The history of accession to the CoE reveals that for a country to meet the membership criteria, the organization demands that it have a rather basic democratic regime while also fulfilling the CoE's agendas on the rule of law and human rights." ${ }^{11}$ This admission policy emerged, for example, from the accession of Portugal and Spain shortly after the collapse of their respective dictatorial regimes. ${ }^{12}$ Other admission cases also suggest that a state may join

Heinrich Klebes, "Membership in International Organizations and National Constitutional Law: A Case Study of the Law and Practice of the Council of Europe", 69 Saint Louis-Warsaw Transatlantic Law Journal (1999), 69-85, at 75-77. This condition has been employed by PACE since the fall of the Berlin Wall. See, e.g., PACE Opinion No.153 (1990) on Hungary's membership application and Opinion No.154 (1990) on Poland's membership application.

10 Chapter I of the Statute provides, inter alia, that " $\mathrm{t}]$ he aim of the Council of Europe is to achieve a greater unity between its members for the purpose of safeguarding and realising the ideals and principles which are their common heritage and facilitating their economic and social progress".

11 Elizabeth Evenson, "Reforms Ahead: Enlargement of the Council of Europe and the Future of the Strasbourg System", 1(2) Human Rights Law Review (2001), 219-242, at 223.

12 Hans Winkler, "Democracy and Human Rights in Europe: A Survey of the Admission Practice of the Council of Europe", 47 Austrian Journal of Public International Law (1995), 147-172, at 149. This article does not aim to provide a comprehensive analysis of all the 
the organization even before fulfilling all the membership criteria, provided that it is committed to improving standards of human rights and the rule of law. To illustrate this point, when Russia joined the CoE in 1996, it failed to meet important membership requirements. ${ }^{13}$ These were outlined in a report filed a month before Russia's accession, in which a CoE rapporteur concluded that "Russia [did] not ... meet all Council of Europe standards". ${ }^{14}$ At the same time, the rapporteur stated that "integration [was] better than isolation [and] cooperation [was] better than confrontation".15 This lack of fulfilment of membership requirements was also recognized with regard to the accession of Romania and several other countries. ${ }^{16}$

The foregoing does not suggest that a state can join the CoE without fulfilling certain standards on human rights and the rule of law. The CoE has demonstrated that compliance with minimum human rights standards is non-negotiable. On these grounds, the $\mathrm{CoE}$ refused to grant membership to Belarus, for example, for its failure to abolish capital punishment.

At the same time, it may be observed that the CoE has followed a policy termed "advance instalment on trust"17 by granting membership to some states that did not, strictly speaking, fulfil some of the membership criteria but promised to work toward realization of the organization's aim in the post-accession phase.

This admission-friendly history is perhaps understandable. By granting membership to new states, the $\mathrm{CoE}$ empowers itself to monitor the situation in the area of human rights and the rule of law in those countries. One of the most important features of this monitoring is the ability of the ECtHR to decide on human rights complaints against $\mathrm{CoE}$ member states. The $\mathrm{CoE}$ can thus

cases of admission to the CoE. It only aims to discuss the cases of admission to the $\mathrm{CoE}$ that either did not fully comply with the membership requirements or had unresolved territorial or political disputes.

13 Leo Zwaak, "The Council and the Conflict in Chechnya", 18(2) Netherlands Quarterly of Human Rights (2000), 275-303, at 179-182; Bill Bowring, "Russia's Accession to the Council of Europe and Human Rights: Compliance or Cross-Purposes?", 6 European Human Rights Law Review (1997), 628-643.

14 Ernst Muehlemann, "Russia's Request for Membership of the Council of Europe", Council of Europe, Document 7443 (2 January 1996).

15 Ibid. See also Pamela A. Jordan, "Russia's Accession to the Council of Europe and Compliance with European Human Rights Norms", 2 Demokratizatsiya (2003), 281-296.

16 See Winkler, op.cit. note 11, 164. See also PACE Opinion No.188 (1995) on the application by Moldova for membership of the Council.

17 Jean Petaux, Democracy and Human Rights for Europe: The Council of Europe's Contribution (Council of Europe Publishing, Strasbourg, 2009), 125. 
realize its aims by granting membership to new states. On the other hand, the Council's refusal to grant membership to states that are willing to comply with the CoE's basic membership criteria could, in fact, go against its raison d'être.

Overall, the foregoing suggests that membership in the Council is as much in the interest of potential candidates as it is in the interest of the organization. It is for this reason that membership in the $\mathrm{CoE}$ is conditioned on the fulfillment of basic standards concerning human rights and rule of law. Against this background, this article will examine both Kosovo's ability to fulfill basic human rights standards and the Council's initiative to explore different modes of cooperation with Kosovo, including in the context of membership.

\subsection{Ability to Exercise Control over Territory: Territorial Disputes}

When the Council granted membership to Azerbaijan and Moldova in 2001 and 1995, respectively, they were involved in disputes in connection with parts of their territories, Nagorno-Karabakh and Transdniestria, respectively. ${ }^{18}$

With regard to the admission of Azerbaijan and Armenia (the latter became a member in 2001), PACE recommended that their "membership would also help to establish a climate of confidence in the region, thus contributing to a peaceful solution of the Nagorno-Karabakh conflict". ${ }^{19}$

Furthermore, at the time when Russia became a member of the CoE (in 1996), its troops were present in Moldova, a member of the organization. In Opinion 193 concerning Russia's application for membership in the CoE, PACE called for "the withdrawal of the [Russian] 14th Army and its equipment from the territory of Moldova within a time-limit of three years", ${ }^{20}$ a commitment that Russia has not implemented to this day. Moldova chose not to challenge Russia's membership on account of the latter's activities in Transdniestria.

The foregoing suggests that unresolved political disputes involving candidate states have not discouraged the Council from welcoming new members.

18 Ilaşcu and Others v. Moldova and Russia, ECtHR Judgment (8 July 2004) Application No.48787/99; Catan and Others v. Moldova and Russia, ECtHR (19 October 2012) Application Nos.43370/4, 8252/05, and 18454/o6; Sargsyan v. Azerbaijan, ECtHR Decision of the Grand Chamber (14 December 2011) Application No.40167/o6.

19 Jacques Baumel, "Azerbaijan's application for membership of the Council of Europe", Document 8748 of the Committee on Political Affairs (23 May 2000), available at <https:// assembly.coe.int/nw/xml/XRef/X2H-Xref-ViewHTML.asp?FileID=8943\&lang=en >; Demetrio Volcic, "Armenia's application for membership of the Council of Europe", Document 8747 of the Committee on Political Affairs (23 May 200o), available at <http://www .assembly.coe.int/nw/xml/XRef/X2H-Xref-ViewHTML.asp?FileID=8942\&lang=en>. PACE, Opinion No.193, "Application by Russia for membership of the Council of Europe", 26 January 1996, para.10.9. 
To the contrary, membership was granted to mitigate such tensions, for instance, when membership was granted to Armenia and Azerbaijan to mitigate tensions over Nagorno-Karabakh, or to Russia, in an effort to resolve tensions in Moldova. ${ }^{21}$ This admission history is highly relevant in the context of Kosovo's path to the Council, as it reveals that political relations between Kosovo and Serbia per se may not present an obstacle. To the contrary, the admission process may be used in mitigating such tensions.

\section{Law and Politics in Kosovo's Quest for CoE Membership}

Accession to an international organization can be particularly challenging for an applicant state that has unresolved political issues with an existing member. The CoE's admission history reveals that, at the time when new member states were joining the organization, there was only one case where an existing member state had a serious disagreement with an applicant state regarding their statehood or territory. That was the case of Moldova, which had concerns about Russia's involvement in its territory when the latter applied for CoE membership. Moldova did not challenge Russia's admission, hoping that Russia would honor its commitment to withdraw its army from Transdniestria. ${ }^{22}$ Another example that deserves attention is the admission of Armenia and Azerbaijan. At the time when these states were seeking CoE membership, there was already tension between them with regard to Nagorno-Karabakh. It was not possible for either of them to hinder the other's admission, however, since they both joined the organization on the same day. ${ }^{23}$

The desire of Kosovo's authorities to join the Council comes while Serbia, a member of the organization, still considers Kosovo to be part of its territory. In this regard, Serbia could argue, first, that Kosovo is not a state, and, second, that

21 It has been argued that the CoE has made the "peaceful solution of conflicts" an additional membership requirement. However, Professor Eckart Klein observes that "the Council did not insist on the complete fulfilment of this admission requirement, rather had it incorporated into the commitments which the States since 1993 had to accept upon accession obligating them to resolve conflicts by peaceful means". See Eckart Klein, "Membership and Observer Status", in Stefanie Schmahl and Marten Breuer (eds.), The Council of Europe: Its Law and Policies (Oxford University Press, Oxford, 2017), 48.

22 PACE Opinion No.193 provided for that expectation. See Opinion No.193, op.cit. 19, para.10.

23 Armenia and Azerbaijan joined the CoE on 25 January 2001. For further information, see <https:/www.coe.int/en/web/portal/armenia> and <https://www.coe.int/en/web/ portal/azerbaijan>. 
Kosovo's authorities do not exercise de jure jurisdiction or de facto control over the territory. ${ }^{24}$ The first issue could be raised under Article 4 of the Statute, as it refers to the "State", and the second issue, under Article 3 of the Statute, insofar as it refers to "jurisdiction". The latter could also be raised in relation to Article 1 of the ECHR. ${ }^{25}$ It is not clear whether the Council would examine any of these issues formally, given that the vast majority of its member states have recognized Kosovo. At the same time, the Council could consider the question of whether Kosovo is able to fulfil the membership criteria, including its ability to secure Convention rights throughout its territory. In that context, the issue of jurisdiction, which also has a territorial aspect, may become important. ${ }^{26}$

The next section will discuss Kosovo's ability to comply with CoE membership criteria by taking into account, where applicable, relevant political considerations.

4

Kosovo's Ability to Comply with CoE Membership Criteria

\subsection{Who Exercises de Jure Jurisdiction over Kosovo's Territory?}

According to Professor Ryngaert, "[j]urisdiction is an aspect of a state's sovereignty, as the right to prescribe and enforce laws is an essential component of statehood". ${ }^{27}$ The ECtHR has maintained that a state exercises de jure territorial jurisdiction over its territory even when that territory is under de facto

24 It should be noted that Serbia's discourse on Kosovo has oscillated over the years. In July 2017, Serbian President Aleksandar Vucic wrote an article on Kosovo in the Serbian newspaper Blic in which he said that it was high time that people "stopped putting their heads in the sand" and "got real" on Kosovo. Some commentators interpreted Vucic's remarks as a call for an internal dialogue with the aim of removing any mention of Kosovo from Serbia's Constitution. At the time of the writing of this article, however, Serbia continues to make all possible efforts to block Kosovo's accession to international organizations. See, generally, Marcus Tanner, "Might Vucic Become Serbia's de Gaulle on Kosovo?", BalkanInsight (1 August 2017), available at <https://www.balkaninsight.com/en/article/mightvucic-become-serbia-s-de-gaulle-on-kosovo--08-01-2017>; "Serbia to do 'everything' to prevent Pristina's Interpol bid", b92 (7 August 2017), available at <http://www.b92.net/ eng/news/politics.php?yyy $=2017 \& \mathrm{~mm}=08 \& \mathrm{dd}=07 \&$ nav_id $=102004>$.

25 Art.1 of the ECHR provides that "[t]he High Contracting Parties shall secure to everyone within their jurisdiction the rights and freedoms defined in Section I of this Convention".

26 Issues of extraterritorial jurisdiction remain outside the scope of this analysis.

27 Cedric Ryngaert, "The concept of jurisdiction in international law", in Alexander Orakhelashvili (ed.), Research Handbook on Jurisdiction and Immunities in International Law (Edward Elgar, Cheltenham, 2015), 50. 
control of another entity. ${ }^{28}$ In this regard, it is important to examine which of the following entities - they all claim a degree of legal ownership over Kosovo's territory-exercises de jure jurisdiction over Kosovo's territory: Kosovo's institutions created after the adoption of Kosovo's Declaration of Independence, Serbia, or the United Nations Interim Administration Mission in Kosovo (UNMIK). ${ }^{29}$

The ECtHR has had the opportunity in its jurisprudence to determine which of these entities exercised jurisdiction over Kosovo under Article 1 of the ECHR. ${ }^{30}$ This jurisprudence, and in particular the case of Azemi v. Serbia, ${ }^{31}, 32$ bears legal and political significance in this regard.

\section{Azemi Case at the Strasbourg Court}

In Azemi v. Serbia, the applicant, a national of Kosovo, alleged that Serbia had violated his rights under Article 6(1) of the Convention by failing to enforce a decision that had been rendered by a court in Kosovo, where Serbia exercised de jure jurisdiction. In this light, the Strasbourg Court considered that the main issue before it was whether or not the facts of the case could be said to have fallen within Serbia's jurisdiction within the meaning of Article 1 of the ECHR. The ECtHR did not find that Serbia exercised jurisdiction in Kosovo. It referred, inter alia, to the circumstances surrounding Kosovo's declaration of independence:

On 17 February 2008 Kosovo proclaimed its independence, having been subsequently recognised as independent by at least 89 States. On 15 June 2008 the Constitution of Kosovo was adopted. On 10 September 2012, apart from the exercise of certain "residual responsibilities" by UNMIK, the end

28 See Cyprus v. Turkey, ECtHR Judgment (19 May 2001) Application No.25781/94; Ilaşcu and Others, op.cit. note 17; Ivanţoc and Others v. Moldova and Russia, ECtHR Judgment (15 November 2011) Application No.23687/05; Catan and Others, op.cit. note 17.

29 See United Nations Security Council Resolution 1244 (1999). For more on UNMIK's mandate, see "Mandate", unMIK website, available at <https://unmik.unmissions.org/ mandate $>$.

30 This article does not provide a comprehensive analysis of the competing claims over Kosovo's territory. It only examines the approach taken by the CoE's institutions in relation to Kosovo.

31 For a lengthy discussion of this case, see Kushtrim Istrefi, "Azemi v Serbia: discontinuity of Serbia's de jure jurisdiction over Kosovo", 4 European Human Rights Law Review (2014), 388-394.

32 Azemi v. Serbia, ECtHR Decision on Admissibility (5 November 2013) Application No.11209/og, 46 . 
of "supervised independence" was declared. In these circumstances, the Court is satisfied that there existed objective limitations which prevented Serbia from securing ... rights and freedoms in Kosovo. ${ }^{33}$

It is noteworthy that the ECtHR referred to the change of public power in Kosovo from UNMIK to Kosovo's newly established institutions, which took place subsequent to the declaration of independence. These remarks were significant for determining which authorities exercised de jure jurisdiction over the territory. ${ }^{34}$ This fact becomes clear from the ECtHR's reasoning in the case of Behrami, which was decided prior to the adoption of Kosovo's declaration of independence. In its decision, the Strasbourg Court followed the presumption that the Federal Republic of Yugoslavia (FRY $)^{35}$ exercised de jure jurisdiction over Kosovo. In Behrami, the ECtHR held:

While the [United Nations Security Council] foresaw a progressive transfer to the local authorities of UNMIK's responsibilities, there is no evidence that either the security or civil situation had relevantly changed by the dates of the present events. Kosovo was, therefore, on those dates under the effective control of the international presences which exercised the public powers normally exercised by the Government of the FRY. ${ }^{36}$

Furthermore, a comparison of how the ECtHR referred to the applicants in both cases shows an acknowledgment on the part of the Strasbourg Court of the effects of Kosovo's Declaration of Independence. In the case of Azemi, the ECtHR described the applicant as "a national of Kosovo" living in "Ferizaj,

33 Ibid.

34 International judges from the European Union Rule of Law Mission in Kosovo (EULEx) held that the UNMIK interim administration had ended. See SoE v. A.A., Decision SCA-og0042 of the mixed panel of EULEX judges of the Special Chamber of the Supreme Court of Kosovo on Privatization Agency of Kosovo Related Matters (29 November 2012), 4. Judgments and decisions of the EULEx judges are available at $<\mathrm{http}$ ://www.eulex-kosovo.eu $>$. While the issue of state succession to the FRY remains controversial, Serbia claims that the State Union of Serbia and Montenegro is the successor to the FRY and that Serbia is the successor to the State Union of Serbia and Montenegro. See, generally, Application of the Convention on the Prevention and Punishment of the Crime of Genocide (Bosnia and Herzegovina v. Serbia and Montenegro), Judgment of the International Court of Justice (22 February 2007), paras.70-75.

36 Behrami v. France and Saramati v. France, Germany and Norway, ECtHR Decision on Admissibility (2 May 2007) Application Nos.71412/o1 and 78166/o1, 70. Emphasis added. 
Kosovo", making no reference to Serbia or UNMIK. ${ }^{37}$ By contrast, in the case of Behrami, in November 2007, shortly before the adoption of Kosovo's declaration of independence, the ECtHR described the applicant as a resident of "Mitrovica, Kosovo, Republic of Serbia". 38

It should also be noted that in Azemi, the ECtHR examined whether or not Serbia exercised extraterritorial jurisdiction in Kosovo. In this regard, the Court made a noteworthy contrast with the case of Ilaşcu, discussing Russia's interference in the Moldovan region of Transdniestria. This suggests that the Court in Azemi viewed Serbia as a foreign state with respect to Kosovo.

In a more recent judgment related to Kosovo, the Strasbourg Court once again touched on the issue of the authorities responsible for enforcing laws and securing human rights in Kosovo. In D.L. v. Austria, a case concerning the extradition of a citizen of Serbia from Austria to Kosovo, neither the ECtHR nor the Government of Serbia, as a third-party intervener, considered whether any authority other than Kosovo's institutions, namely UNMIK or Serbia, exercised any public power and thus had the duty to ensure the human rights of the applicant in Kosovo. ${ }^{39}$ Furthermore, the Serbian Government went a step further by finding problematic the fact that the Austrian Government had not required diplomatic assurances from Kosovo's authorities with respect to the applicant. ${ }^{40}$ This suggests that Kosovo's authorities had the capacity to engage in such diplomatic functions.

In conclusion, it transpires from the ECtHR's approach to the situation in Kosovo subsequent to its declaration of independence that the Strasbourg Court did not endorse the continuity of Serbia's de jure jurisdiction. This is further reinforced by the absence in Azemi of an assessment of Serbia's positive obligations in Kosovo. In this light, both Azemi and, more recently, D.L. v. Austria signal that, in the view of the Court, no external authority is assumed to exercise de jure jurisdiction over Kosovo. ${ }^{41}$

\section{De Facto Control over the Territory}

At the time of writing, Kosovo's institutions exercise limited control in the northern part of the territory. Certain state prerogatives, including the judiciary and security enforcement, are exercised with the assistance of the European Union Rule of Law Mission in Kosovo (EULEX), the nato Kosovo Force

37 Azemi, op.cit. note 31, para.1.

38 Behrami, op.cit. note $35,1$.

39 D.L. v. Austria, ECtHR Judgment (7 December 2017) Application No.34999/16.

$40 \quad$ Ibid., 51.

41 See Istrefi, op.cit. note 30. 
(KFOR), and other institutions. ${ }^{42}$ Therefore, the question remains whether Kosovo is able to ensure, inter alia, rights under the ECHR for people living in the northern part of the country. ${ }^{43}$

The aforementioned question may be explored in light of the 2013 EU-facilitated agreement between Belgrade and Pristina. ${ }^{44}$ The agreement states, inter alia, that "the judicial authorities [in the northern part of Kosovo] will be integrated and operate within ... [Kosovo's] legal framework".45 It provides that, from the legal standpoint, the country's unitary system is not challenged. The integration of the Kosovo Serb community and Serb-majority municipalities in Kosovo's legal order is also provided for in the 2015 agreement reached between the prime ministers of Kosovo and Serbia. ${ }^{46}$ This integration process got under way in particular in October 2017, when 40 judges and 13 prosecutors, mostly of Serb ethnicity, joined Kosovo's judiciary in the northern part of Kosovo. ${ }^{47}$

The history of accession to the Council shows that the lack of de facto control by national authorities over every part of a state's territory is not an obstacle to that country's admission to the organization. ${ }^{48}$ At the same time, it is not

42 Wolfgang Benedek, "The Role of the International Community with Regard to Human Rights and Democracy in Bosnia and Herzegovina, Kosovo and Macedonia - A Comparative View", in Wolfgang Benedek (ed.), Lessons (Not) Learned with Regard to Human Rights and Democracy: A Comparison of Bosnia and Herzegovina, Kosovo and Macedonia (NWv, BWV, and Intersentia, Vienna, 2009), 14-29, at 19; Erika de Wet, "The Governance of Kosovo: Security Council Resolution 1244 and the Establishment and Functioning of EULEX", 103(1) American Journal of International Law (2009), 83-96.

43 The northern part of the country is mostly inhabited by Kosovo Serbs, generally believed not to be proponents of Kosovo's independence.

44 Law No.04/L-199 of 27 June 2013 on Ratification of the First International Agreement of Principles Governing the Normalization of Relations Between the Republic of Kosovo and the Republic of Serbia, available at <http://www.kuvendikosoves.org/common/docs/ ligjet/Law\%20on\%2oratification\%20of\%2oagreement\%2o-normalization\%2oof\%2ore lations\%2obetween\%2oKosovo\%20and\%2oSerbia.pdf >. Ibid., Art.10.

46 See "Agreement on Association/Community of Serb majority municipalities in Kosovo general principles/main elements", 25 August 2015, available at <http://eeas.europa.eu/ statements-eeas/docs/150825_02_association-community-of-serb-majority-municipali ties-in-kosovo-general-principles-main-elements_en.pdf >.

47 See "Prosecutors and judges of the non-majority community swear the oath in front of President Thaçi", press release (24 October 2017), available at <http://www.president -ksgov.net/en/news/prosecutors-and-judges-of-the-non-majority-community-swear-the -oath-in-front-of-president-thaci>.

48 For the situation in Moldova and Azerbaijan, see generally Ilaşcu and Others, op.cit. note 17; Catan and Others, op.cit. note 17; Sargsyan v. Azerbaijan, op.cit. note 17. 
certain whether or not Serbia could raise such an issue in the case of Kosovo. Hence, the ability of Kosovo's authorities to exercise their powers throughout the country would certainly minimize the negative impact of any such possible claims in the accession process.

\subsection{Willingness and Ability to Comply with the Democratic Values of the Rule of Law and Human Rights}

Provided that the question of Kosovo's membership were put on the Council's agenda, PACE would assign rapporteurs and would conduct fact-finding missions to examine the situation in Kosovo regarding human rights and the rule of law. Based on their findings, it would then tailor a set of membership requirements. ${ }^{49}$ Ordinarily, these requirements include, but are not limited to, establishing particular mechanisms, adopting laws and treaties, undertaking specific actions, and adopting particular policies. ${ }^{50}$

PACE has already issued reports with respect to Kosovo from which it has emerged that the areas that could require improvement include political interference in the work of the judiciary, the legislature, the media, and other regulatory institutions; corruption; organized crime; and integration of the Roma population..$^{51}$ In addition, PACE appears to have two particular requirements for Kosovo: first, that it cooperate with Serbia and, second, that it establish a specialized judicial organ to try certain crimes committed during and after the 1998-1999 Kosovo conflict. Concerning the first question, the EU has acknowledged Kosovo's commitment to cooperate with Serbia in the framework of the so-called Brussels talks. ${ }^{52}$ Since the dialogue between Kosovo and Serbia is ongoing, however, PACE may require continuation of the dialogue and effective implementation of the agreements reached between the two parties. Concerning the second question, Kosovo's Parliament has established international Specialist Chambers and a Specialist Prosecutor's Office ${ }^{53}$ operating in The Hague to deal with cases in relation to a $2010 \mathrm{CoE}$ report. ${ }^{54}$

\footnotetext{
49 See, generally, Winkler, op.cit. note $11,147-172$.

$50 \quad$ Ibid.

51 For an overview of PACE's reports on Kosovo prior to September 2013, see Lowell West, "Kosovo's Path to the Council of Europe: Identifying Procedures, Obstacles and Solutions for Membership", Policy Report, Group for Legal and Political Studies (2013), 13-17.

52 See "Statement by High Representative/Vice-President Federica Mogherini following the meeting of the E U-facilitated dialogue", European Union External Action website (25 August 2015), available at <http://www.eeas.europa.eu/statements-eeas/2015/150825_02_en.htm>.

53 Legal documents concerning the establishment of Kosovo's Specialist Chambers and Specialist Prosecutor's Office are available at <https://www.scp-ks.org/en/documents > .

54 Dick Marty, "Inhuman treatment of people and illicit trafficking in human organs in Kosovo", Document As/Jur 46 of the PACE Committee on Legal Affairs and Human Rights
} 
At the time of writing, however, it is possible to examine Kosovo's ability to incorporate and apply CoE conventions and the Strasbourg Court's case law in its domestic legal order.

$$
\begin{aligned}
& \text { The Place of CoE Conventions and the Strasbourg Court's Case } \\
& \text { Law in Kosovo's Legal Order }
\end{aligned}
$$

In its Constitution, Kosovo has granted direct effect and supremacy over its domestic laws to eight international human rights instruments. ${ }^{55}$ These instruments include the ECHR and its protocols and the Council of Europe Framework Convention for the Protection of National Minorities (Framework Convention). ${ }^{56}$ Furthermore, Article 53 of Kosovo's Constitution provides that all "human rights and fundamental freedoms guaranteed by [the] Constitution shall be interpreted consistent with the court decisions of the European Court of Human Rights." 57

The case law of Kosovo's Constitutional Court reveals that the ECHR and the ECtHR's case law are an important source in its decision-making. ${ }^{58}$

(12 December 2010), available at <http://www.assembly.coe.int/CommitteeDocs/2010/aj doc46201oprov.pdf $>$. The report suggests that a handful of members of the Kosovo Liberation Army may have participated in abductions, beatings, summary executions, and, in some cases, forced removal of human organs.

55 See Art.22 of the Constitution of the Republic of Kosovo (adopted on 9 April 2008) with subsequent amendments I-XXII (7 September 2012), amendment XXIII (26 March 2013) and amendment XXIV (5 August 2015). See also Kushtrim Istrefi, "Constitutional Domestication of International Human Rights in the Kosovo Legal Order", 1 E Drejta, Pravo, Law (2013), 267-283.

$5^{6}$ The remaining instruments listed in Art.22 of Kosovo's Constitution are the Universal Declaration of Human Rights; the International Covenant on Civil and Political Rights and its Protocols; the Convention on the Elimination of All Forms of Racial Discrimination; the Convention on the Elimination of All Forms of Discrimination against Women; the Convention on the Rights of the Child; and the Convention against Torture and Other Cruel, Inhumane or Degrading Treatment or Punishment.

57 Kosovo's Constitution has been adopted in three official language versions: Albanian, English, and Serbian. All quotations from Kosovo's Constitution cited in this article are taken from the official English version.

$5^{8}$ Around 92 percent of all decisions of the Kosovo Constitutional Court include a reference to the case law of the ECtHR. The Director of the Legal Office of the Kosovo Constitutional Court provided this information to the author on 19 April 2018. See also Snezhana Botusharova, "The Constitutional Court of Kosovo and the European Court of Human Rights", in Enver Hasani, Péter Paczolay, and Michael Riegner (eds.), Constitutional Justice in Southeast Europe (Nomos, Baden-Baden, 2012), 71-91. 
Furthermore, the President of Kosovo has referred to the ECHR in her reviews of the laws adopted by the Kosovo Assembly. ${ }^{59}$ In particular, the President was of the view that some provisions of the Criminal Code adopted by the Kosovo Assembly on 20 April 2012 did not comply with the ECHR and returned the Criminal Code to the Assembly for reconsideration. The Assembly then modified the controversial provisions noted by the President. ${ }^{60}$ Similarly, the case law of Kosovo's regular courts reveals that they have been increasingly referring to the ECHR and the ECtHR's case law in their interpretation of statutes passed by the Kosovo Assembly, its legislative body. ${ }^{61}$

Concerning the Framework Convention, it should be noted that it "was deliberately drafted as a 'framework' convention, as it was assumed that its provisions would not be directly enforceable". ${ }^{62}$ Regardless of the nature of the instrument, Kosovo's Constitutional Court has referred to the Framework Convention to quash a decision made by a Kosovo municipality: in the Kurtishi case, the Constitutional Court stated that the municipal statute at issue had to be reviewed not only in light of the Constitution but also the Framework Convention, which enjoyed supremacy over Kosovo law. ${ }^{63}$

This commitment on the part of Kosovo to the Council's key human rights instruments and to the Strasbourg Court's case law reveals, at a minimum, Kosovo's willingness to endorse and promote the organization's aims.

59 According to Art.84 of Kosovo's Constitution, the President "has the right to return adopted laws for reconsideration, when he/she considers them to be harmful to the legitimate interests of the Republic of Kosovo or one or more Communities".

6o See "President Jahjaga returns to the Assembly the Criminal Code of the Republic of Kosovo for review", website of the President of the Republic of Kosovo, available at $<$ http://www.president-ksgov.net/?page =2,6,2320 >.

61 In cases KP No.33/11 and KP No.10o/12 of the Basic Court of Ferizaj, Judge Hyseni employed the ECtHR's concept of 'reasonable suspicion' by referring to Fox, Campbell and Hartley $v$. The United Kingdom. In the decision of the same court in case P No.355/12, a reference to I.A. v. France was made with respect to measures to ensure a defendant's presence in court. For references to ECtHR case law concerning the interpretation of measures to ensure a defendant's presence in court, the principle of in dubio pro reo, and the presumption of innocence, see also the decisions of Judge Agim Maliqi of the Basic Court of Ferizaj, PKR No.38/13 and PKR No.9/2013-P94/12 PR1.

62 Marc Weller, Contested Statehood: Kosovo's Struggle for Independence (Oxford University Press, New York, 2009), 245.

63 Qemailj Kurtisi v. Municipal Assembly of Prizren, Constitutional Court of Kosovo Judgment (18 March 2010), Case No.K.o. 01/og, § 42. 
According to the CoE Statute, a candidate country does not submit a membership application. Instead, an existing member of the Council must request that the Committee of Ministers invite a new country to become a member. In light of this, Kosovo would have to rely on a member of the organization to sponsor its membership.

The membership process is then triggered if at least two-thirds of the Committee members are present and vote in favor of the proposal to invite a new member. The recognition of Kosovo by more than two-thirds of the Council's member states is an indicator that, in principle, Kosovo could ensure the necessary votes in this phase. ${ }^{64}$ At the same time, if some states were reluctant to support Kosovo's membership in the Council, for whatever reason, they might simply choose to not attend the relevant meeting of the Committee. This could delay, if not prevent, Kosovo's accession to the Council. In this regard, it is expected that the first diplomatic battle between Kosovo and Serbia would be over who could convince more states to attend — or not attend-the relevant Committee meeting.

If two-thirds of the Committee members voted in favor of a proposal to invite Kosovo to join the organization, PACE would be called on to tailor the membership criteria and assess Kosovo's fulfillment thereof. The CoE's statutory Resolution 51 provides that "the Committee of Ministers, before inviting a State to become a member ... shall first consult ... [PACE] in accordance with existing practice". ${ }^{65}$ Although PACE's opinions are non-binding, ${ }^{66}$ the Committee has observed its recommendations regarding new members.

PACE recommendations on membership are decided by a two-thirds majority. The voting within PACE for Kosovo's accession may be unpredictable due to its composition. PACE is composed of individuals from different political, ideological, and ethnic backgrounds. Therefore, PACE members may not always have the same view as the government of the country that they represent. For example, an Estonian PACE member from that country's Russianspeaking minority might choose to vote with Russia on Kosovo's statehood,

64 Art.20 of the CoE's Statute provides that accession to the Council requires a two-thirds majority of all of the representatives of the Committee of Ministers.

65 CoE Committee of Ministers, Resolution $5^{1}$ (30), Revision of the Statute, 3 May 1951, appended to the Statute.

66 When the Statute of the Council was being revised, PACE, in Recommendation 1212, made a proposal that its opinions on membership would be binding on the Committee of Ministers; however, the latter rejected the proposal. 
and on those grounds vote against Kosovo's accession to the Council. At the same time, a Spanish PACE member of Catalan ethnicity might not align their position with Spain on Kosovo's statehood, and might favor Kosovo's membership in the Council. In addition, PACE members could be divided over the question of Kosovo's membership depending on whether they favor or reject European integration per se. The rise of populism in this regard might not favor Kosovo's prospects for accession to the Council. It follows that support from the foreign ministry of a particular member of the Council might not necessarily mean that all PACE members from that country would share in that support.

To conclude, the recognition of Kosovo by more than two-thirds of the Council's member states suggests that Kosovo's political status may not be an obstacle to its accession. Furthermore, it should be noted that some states that have not recognized Kosovo's independence supported Kosovo in its accession bid to join the CoE's Venice Commission and the Development Bank. ${ }^{67}$ However, the complex procedure for admission to the Council, including the sponsorship procedure to ensure an invitation to join the Council, the vote on that matter requiring the presence and the vote of at least twothirds of Committee members, and the diverse composition of PACE members, demonstrate instances where Kosovo might stumble in its membership path to the Council.

\section{Conclusions}

PACE has repeatedly stated that Kosovo should not be left outside the legal space of the ECHR and its mechanisms. ${ }^{68}$ In Recommendation 1923 of 2010, PACE stated that the Council's further engagement in Kosovo "should aim at raising standards in the field of democracy, human rights and the rule of law, so that people in Kosovo can enjoy an equivalent level of rights to that upheld

67 Interview with Edon Cana, Consul-General of the Republic of Kosovo to Strasbourg, 1 September 2014, Strasbourg, France.

68 CoE Parliamentary Assembly, Resolution 1375 (2004), "Situation in Kosovo", 29 April 2004; CoE Parliamentary Assembly, Resolution 1453 (2005), "Current Situation in Kosovo”, 21 June 2005; CoE Parliamentary Assembly, Resolution 1417 (2005), "Protection of Human Rights in Kosovo", 25 January 2005; CoE Parliamentary Assembly, Resolution 1595 (2008), "Developments as regards the future status of Kosovo", 22 January 2008; CoE Parliamentary Assembly, Resolution 1739 (2010), "The situation in Kosovo and the role of the Council of Europe", 22 June 2010. 
by the Council of Europe, irrespective of the status of Kosovo". ${ }^{69}$ The Recommendation further reads:

To this end, the Council of Europe should broaden the range of its activities in Kosovo and demonstrate pragmatism, flexibility and imagination in finding formulas which would enable the broadest possible range of Council of Europe activities and mechanisms to apply in Kosovo. ${ }^{70}$

Despite this call, key CoE mechanisms, including access to the Strasbourg Court, remain inapplicable in Kosovo and in relation to its citizens. Indeed, access to such mechanisms can be secured only through Kosovo's membership in the Council.

This article shows that Kosovo is able to fulfill the basic CoE membership criteria and that its contested status by some $\mathrm{CoE}$ members may not hamper its ambition to join the organization. In particular, the article suggests that Kosovo exercises de jure jurisdiction over its territory and is committed to observing the Council's key instruments and the Strasbourg Court's case law. PACE would devise membership criteria if the Committee were to invite Kosovo to become a member. Such requirements might include general standards concerning human rights and the rule of law, as well as specific standards, including the necessity to cooperate with Serbia and with the Kosovo Specialist Chambers and Specialist Prosecutor's Office operating in The Hague.

The recognition of Kosovo's independence by more than two-thirds of Council members is a sign that Kosovo could, in principle, secure the votes necessary to obtain membership. Ten years have passed since Kosovo's Declaration of Independence, and Kosovo's Government has expressed the desire to join the Council. However, the country has not yet sought to initiate a formal procedure for its admission. This raises questions about the possible reasons for this lack of action. One might wonder whether this has been due to passivity on the part of Kosovo diplomacy, the arrangements that could be made under the EUmediated Kosovo-Serbia talks, or geopolitics. Regarding diplomatic passivity, such an explanation is not convincing, as the country has made efforts to join other international organizations and institutions, including those affiliated with the CoE, such as the Venice Commission and the Development Bank. The Kosovo-Serbia talks might play a role in this delay. In particular, it could be

69 CoE Parliamentary Assembly, Recommendation 1923 (2010) Final version, "The situation in Kosovo* and the role of the Council of Europe", available at <http://assembly.coe.int/ $\mathrm{nw} / \mathrm{xml} / \mathrm{XRef} /$ Xref-XML2HTML-en.asp?fileid=17873\&lang=en $>$.

70 CoE Parliamentary Assembly, Resolution 1739, op.cit note 66, para.3. 
argued that states that support Kosovo's independence expect that Kosovo and Serbia might soon reach an agreement by which Serbia will agree to not block Kosovo's membership in international organizations. In this regard, the Eu recently announced that Kosovo and Serbia must reach this type of agreement by the beginning of 2019 if Serbia wants to join the EU. ${ }^{71}$ The eventual success of that agreement could open doors for Kosovo's membership in the UN and other international organizations, including the CoE. However, if the KosovoSerbia talks fail to achieve the desired outcome in the coming months, Kosovo may revitalize its diplomatic efforts to join these international organizations, including the CoE, where states that recognize Kosovo have, in principle, sufficient voting power to decide on its accession.

Lastly, considerations related to geopolitics appear legitimate and might explain why Kosovo's accession to the Council remains uncertain despite its recognition by more than two-thirds of the CoE's member States. Perhaps the countries that support Kosovo's membership are not yet prepared to raise this topic within the organization at a time when its disagreements with Russia, which opposes Kosovo's membership, have reached a tipping point. ${ }^{72}$

To conclude, Kosovo's ability and willingness to meet basic standards on human rights and the rule of law and the recognition of Kosovo by more than two-thirds of CoE members makes Kosovo's objective of joining the CoE a realistic one. At the same time, it appears that actual accession will depend not only on its ability to fulfill the membership criteria but also on the pace and the fruits of the Kosovo-Serbia dialogue and broader geopolitical developments. These make the process of admission as much a matter of law as of politics.

71 Aleksandar Vasovic, "Serbia must reach agreement with Kosovo to join EU by 2025", Reuters (7 February 2018), available at <https://www.reuters.com/article/us-serbia-eu -enlargement/serbia-must-reach-agreement-with-kosovo-to-join-eu-by-2025-idUSKBN ${ }_{1 \mathrm{FR}} \mathrm{JP}>$.

72 See, e.g., PACE Resolution 2132 (2016), in which PACE condemns Russia's annexation of Crimea: CoE Parliamentary Assembly, Resolution 2132 (2016), "Political consequences of the Russian aggression in Ukraine”, 12 October 2016, available at <http://assembly.coe.int/ nw/xml/XRef/Xref-XML2HTML-EN.asp?fileid=23166\&lang=en>. 